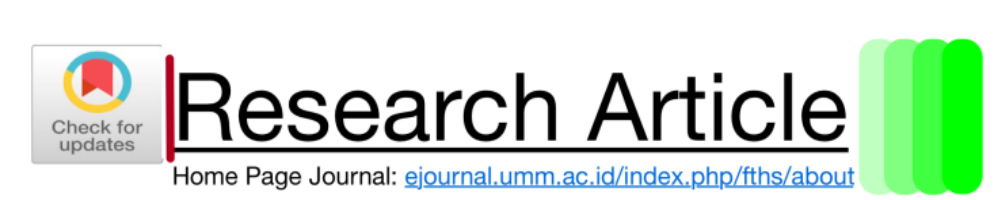

DOI. $10.22219 /$ fths.v5i1.18759

Received: 20 November 2021

Accepted: 25 Januari 2022

Available online: 31 Januari 2022

\title{
Karakteristik Fisikokimia Fruit Leather Apel Manalagi (Malus sylvestris) dengan Penambahan Ekstrak Bunga Telang (Clitoria ternatea) dan Gum Arab
}

\author{
Siti Rima Pratiwi Putri ${ }^{*}$, Elfi Anis Saati ${ }^{1}$, Damat ${ }^{1}$ \\ ${ }^{1}$ Program Studi Teknologi Pangan, Fakultas Pertanian Peternakan, Universitas Muhammadiyah \\ Malang, Malang, Indonesia \\ *Corresponding author email: sitirimapp@gmail.com
}

\begin{abstract}
Manalagi apple is Malanglocal apple that has high pectin content,so it has potential to be processed into fruit leather. However, manalagi apple fruit leather has unattractive color and weak plasticity. The solution that can be used are using natural dye from anthocyanin pigment of butterfly pea flower and gum arabic as hydrocolloid. This research was conducted to determine the interaction, effect and best treatment of differences in concentration of butterfly pea flower extract and gum arabic on the physicochemical characteristics of manalagi apple fruit leather. This study used factorial randomized block design. Factor I is the concentration of butterfly pea flower extract, namely TO (O\%), T1 (5\%), T2 (10\%), T3 (15\%), while the factor II is the concentration of gum arabic, namely G1 (0.9\%), G2 (1.2\%), G3 (1.5\%) with consistent concentration of manalagi apple slurry. The results showed there is interaction between concentration of butterfly pea flower extract and gum arabic on organoleptic scores of manalagi apple fruit leather. Concentration of butterfly pea flower extract significantly affects $\mathrm{pH}$, tensile strength, color intensity, antioxidant activity and organoleptic scores of fruit leather. Concentration of gum arabic significantly affects water content, $p H$, tensile strength and organoleptic scores of fruit leather. The combination of T3G3 (butterfly pea flower extract 15\% and arabic gum 1,5\%) treatment produce the best fruit leather which has attractive appearance $(3,92)$, apple-specific aroma $(3,64)$ and delicious taste $(3,68)$, water content $13.23 \%$, $p H$ value 3.91 , tensile strength $26.35 \mathrm{~N}$, brightness level (L) 41.4, redness level (at) +6.7 , bluish level $\left(b^{-}\right)-0.6$, antioxidant activity $90.62 \%$ and total anthocyanin $1.06 \mathrm{mg} / \mathrm{L}$.
\end{abstract}

Keywords: anthocyanin, antioxidant, butterfly pea, fruit leather, manalagi apple

\begin{abstract}
Abstrak. Apel manalagi merupakan apel lokal Malang dengan kandungan pektin tinggi, sehingga berpotensi diolah menjadi fruit leather. Namun fruit leather apel manalagi memiliki kekurangan pada warna dan tekstur. Solusi yang dapat digunakan adalah penggunaan pewarna alami dari pigmen antosianin bunga telang dan gum arab sebagai hidrokoloid. Penelitian ini bertujuan untuk mengetahui interaksi, pengaruh dan perlakuan terbaik dari perbedaan konsentrasi penambahan ekstrak bunga telang dan gum arab terhadap karakteristik fisiokimia fruit leather apel manalagi. Penelitian menggunakan Rancangan Acak Kelompok (RAK) faktorial. Faktor 1 ialah konsentrasi ekstrak bunga telang yaitu T0 (0\%), T1 (5\%), T2 (10\%), T3 (15\%), sedangkan faktor II ialah konsentrasi gum arab yaitu G1 (0,9\%), G2 (1,2\%), G3 (1,5\%) dengan konsentrasi bubur apel manalagi yang konsisten. Hasil penelitian menunjukkan, bahwa terdapat interaksi konsentrasi ekstrak bunga telang dan gum arab terhadap skor organoleptik fruit leather. Perbedaan konsentrasi ekstrak bunga telang berpengaruh nyata terhadap $\mathrm{pH}$, kuat tarik, intensitas warna, aktivitas antioksidan dan skor organoleptik fruit leather. Perbedaan konsentrasi gum arab
\end{abstract}


berpengaruh nyata terhadap kadar air, $\mathrm{pH}$, kuat tarik dan skor organoleptik fruit leather. Kombinasi perlakuan T3G3 (ekstrak bunga telang 15\% dan gum arab 1,5\%) menghasilkan fruit leather terbaik dengan kenampakan menarik $(3,92)$, aroma khas apel $(3,64)$ dan rasa enak (3,68), kadar air 13,23\%, pH 3,91, kuat tarik 26,35 N, tingkat kecerahan (L) 41,4, tingkat kemerahan $(\mathrm{a}+)+6,7$, tingkat kebiruan $\left(\mathrm{b}^{-}\right)-0,6$, aktivitas antioksidan 90,62\% dan total antosianin $1,06 \mathrm{mg} / \mathrm{L}$.

Kata kunci: antosianin, antioksidan, apel manalagi, bunga telang, fruit leather

\section{PENDAHULUAN}

Apel manalagi merupakan salah satu jenis apel lokal Malang yang memiliki tekstur lebih keras dengan kandungan pektin yang lebih tinggi dibanding jenis lainnya, yaitu sebesar 1,28\% (Putri dkk., 2017). Apel manalagi berpotensi untuk diolah menjadi fruit leather karena proses pembuatannya memanfaatkan kandungan pektin buah. Selain itu, buah apel manalagi memiliki kandungan vitamin $\mathrm{C}$ dan kuersetin yang dapat berperan sebagai antioksidan. Nilai $\mathrm{IC}_{50}$ bubur buah apel manalagi mencapai 66,34 ppm (Zaddana dkk., 2020). Fruit leather adalah salah satu olahan pangan berbentuk lembaran tipis yang terbuat dari bubur buah yang dikeringkan. Fruit leather termasuk cemilan sehat yang belum banyak diketahui oleh masyarakat Indonesia, padahal cara pembuatannya cukup mudah. Masalah yang sering timbul dalam pembuatan fruit leather adalah warna yang kurang menarik dan tekstur yang kurang plastis.

Olahan dari apel yang dilakukan blanching memiliki warna kuning pucat yang kurang menarik, sehingga perlu penambahan pewarna (Anwar dan Wahyuni, 2020). Penggunaan pewarna alami dari bunga telang dan gum arab sebagai hidrokoloid dapat menjadi solusi untuk meningkatkan kualitas fruit leather. Bunga telang berwarna biru keunguan memiliki pigmen antosianin yang mencapai $56,82 \mathrm{mg} / \mathrm{mL}$ (Saati dkk., 2018). Ekstrak bunga telang memiliki nilai $\mathrm{IC}_{50}$ sebesar 41,36 ppm (Andriani dan Murtisiwi, 2020). Bunga telang sebagai pewarna alami dapat membantu mengurangi penggunaan pewarna sintetik dan meningkatkan nilai fungsional produk. Bunga telang sebagai pewarna alami telah digunakan pada produk pangan seperti ketan di Malaysia, dawet (Saati dkk., 2018) dan yogurt (Dewi dkk., 2019). Tekstur fruit leather dapat ditingkatkan dengan penambahan hidrokoloid seperti gum arab. Gum arab memiliki kelebihan yaitu kelarutan dalam air yang lebih tinggi dibanding hidrokoloid lain (Astuti dkk., 2015). Selain itu, memiliki sifat yang dapat mempertahankan flavor dari bahan pangan (Christiana dkk., 2015). Penelitian penambahan gum arab pada fruit leather sudah banyak dilakukan, antara lain pada fruit leather nanas (Sinaga dkk., 2017), semangka-wortel (Putri dkk., 2016) dan pisang raja (Dimyati dkk., 2020). Namun, penelitian tentang penambahan ekstrak bunga telang dan gum arab pada fruit leather apel manalagi belum dilakukan. 
Penelitian ini diharapkan dapat mengetahui konsentrasi ekstrak bunga telang dan gum arab dengan hasil fruit leather apel manalagi yang memiliki karakteristik fisikokimia terbaik. Selain itu, diharapkan produk ini menjadi cemilan sehat yang dapat memberikan manfaat fungsional serta meningkatkan keanekaragaman produk olahan dari apel manalagi dan bunga telang.

\section{METODE PENELITIAN}

\section{Bahan}

Bahan yang digunakan dalam pembuatan fruit leather terdiri dari apel manalagi (Malus sylvestris) yang diperoleh dari kebun di daerah Kecamatan Bumiaji-Kota Batu (umur panen 5 bulan), bunga telang (Clitoria ternatea) berwarna biru keunguan yang sudah dikeringkan yang berasal dari Desa JunrejoKota Batu, gum arab merk Tic Gums dari Toko Mitra Jaya Chemical-Kota Bekasi, gula pasir, asam sitrat (food grade) dan air.

Alat

Alat yang digunakan meliputi cabinet dryer, oven (tipe WTC binder), timbangan analitik (Pioneer Ohaus PA413), pH meter (WTW Caliesys Lab 875), waterbath, texture analyzer (Shimadzu (E.Z. Test EZ-SX 500N)), color reader (Konica Minolta CR-10) dan spektrofotometer UV-Vis (Genesys 20).

\section{Desain Penelitian}

Penelitian ini menggunakan Rancangan Acak Kelompok (RAK) faktorial dengan 2 faktor. Faktor 1 adalah konsentrasi ekstrak bunga telang (T) $(0 \%, 5 \%$, $10 \%$ dan 15\%) dan faktor 2 adalah konsentrasi gum arab (G) (0,9\%, 1,2\% dan 1,5\%) sehingga diperoleh 12 kombinasi perlakuan yang diulangi sebanyak 2 kali.

\section{Pembuatan Bubur Apel Manalagi}

Bubur apel manalagi dibuat menggunakan metode Ramadhani (2016) dengan modifikasi. Buah apel manalagi dibersihkan, dilakukan pengecilan ukuran dan steam blanching pada suhu $80^{\circ} \mathrm{C}$ selama 8 menit. Buah apel manalagi dihancurkan dengan penambahan air sebanyak $50 \%$.

\section{Ekstraksi Bunga Telang}

Ekstraksi bunga telang menggunakan metode Zussiva dkk. (2012) dengan modifikasi. Bunga telang sebanyak $15 \mathrm{~g}$ diesktraksi menggunakan pelarut aquades: asam sitrat (98:2) sebanyak $500 \mathrm{~mL}$ dengan suhu $60^{\circ} \mathrm{C}$ selama 30 menit.

\section{Pembuatan Fruit Leather Apel Manalagi}

Fruit leather dibuat menggunakan metode Ramadhani (2016) dengan modifikasi. Bubur apel dengan konsentrasi yang konsisten ditambahkan dengan gula $30 \%$, asam sitrat $0,1 \%$, gum arab dan ekstrak bunga telang sesuai perlakuan. Pemanasan dilakukan dengan suhu $70^{\circ} \mathrm{C}$ selama 2 menit, selanjutnya dicetak di 
loyang ukuran 20x20 $\mathrm{cm}$ dengan ketebalan $\pm 3 \mathrm{~mm}$ dan dilakukan pengeringan menggunakan cabinet dryer dengan suhu $65^{\circ} \mathrm{C}$ selama 20 jam.

\section{Parameter Penelitian}

Parameter pada penelitian ini meliputi parameter kimia (kadar air (AOAC, 2005), nilai pH (BSN, 2004)), fisika (kuat tarik (ASTM, 1993), intensitas warna (Souripet, 2015)), aktivitas antioksidan (Yue dan $\mathrm{Xu}, 2008$ ), total antosianin (AOAC, 2005) dan organoleptik (kenampakan, aroma, rasa) (Rahmi, 2013).

\section{Analisis Data}

Pengolahan data dilakukan menggunakan metode analisa sidik ragam (ANOVA) yang dilanjutkan dengan uji pembeda menggunakan uji DMRT (Duncan Multiple Range Test), Penentuan perlakuan terbaik menggunakan metode de Garmo dkk. (1984).

\section{HASIL DAN PEMBAHASAN}

\section{Karakteristik Bahan Baku}

Bahan baku berupa bubur buah apel manalagi dan ekstrak bunga telang dianalisa parameter nilai $\mathrm{pH}$, aktivitas antioksidan dan total antosianin untuk mengetahui karakteristik dan perubahan kandungan bahan sebelum dan sesudah diolah menjadi produk.

Tabel 1. Karakteristik Bahan Baku

\begin{tabular}{lcc}
\hline \multirow{2}{*}{ Parameter } & \multicolumn{2}{c}{ Bahan Baku } \\
\cline { 2 - 3 } & Ekstrak Bunga Telang & Bubur Apel Manalagi \\
\hline Nilai Ph & 2,42 & 3,78 \\
Aktivitas Antioksidan (\%) & 70,57 & 95,15 \\
Total Antosianin (mg/L) & 4,17 & - \\
Vitamin C (mg/100 g) & - & $12,08^{*}$ \\
\hline
\end{tabular}

Sumber: *) Putri dkk., 2017

Ekstrak bunga telang memiliki nilai $\mathrm{pH}$ yang rendah karena proses ekstraksi menggunakan larutan asam sitrat $2 \%$. Kondisi yang asam selama proses ekstraksi menyebabkan senyawa antosianin lebih stabil (Saati dkk., 2018). Nilai pH bubur apel manalagi sesuai dengan pernyataan Susanto dan Setyohadi (2011) yang menyatakan bahwa apel manalagi memiliki nilai $\mathrm{pH}$ yang lebih tinggi dibandingkan jenis apel anna dan romebeauty, yaitu sebesar 4,27. Apel memiliki senyawa fitokimia yang berperan sebagai antioksidan seperti vitamin $\mathrm{C}$ sebesar 12,08 mg/100g (Putri dkk., 2017) dan kuersetin sebesar 406,57 mg/L. Ekstrak bunga telang memiliki pigmen antosianin berwarna biru keunguan yang dapat berperan sebagai antioksidan. Bunga telang memiliki nilai IC $_{50}$ mencapai 41,36 ppm (Andriani dan Murtisiwi, 2020). Total antosianin ekstrak bunga telang hasil 
penelitian Zussiva dkk. (2012) sebesar 6,35 mg/L. Perbedaaan hasil dapat dipengaruhi kondisi bunga telang yang digunakan.

\section{Kadar Air Fruit Leather Apel Manalagi}

Berdasarkan hasil analisis ragam menunjukkan bahwa tidak terjadi interaksi antara konsentrasi ekstrak bunga telang dan gum arab. Secara terpisah konsentrasi ekstrak bunga telang yang berbeda tidak berpengaruh nyata dan konsentrasi gum arab berpengaruh nyata $(\alpha=5 \%)$ terhadap kadar air fruit leather apel manalagi.

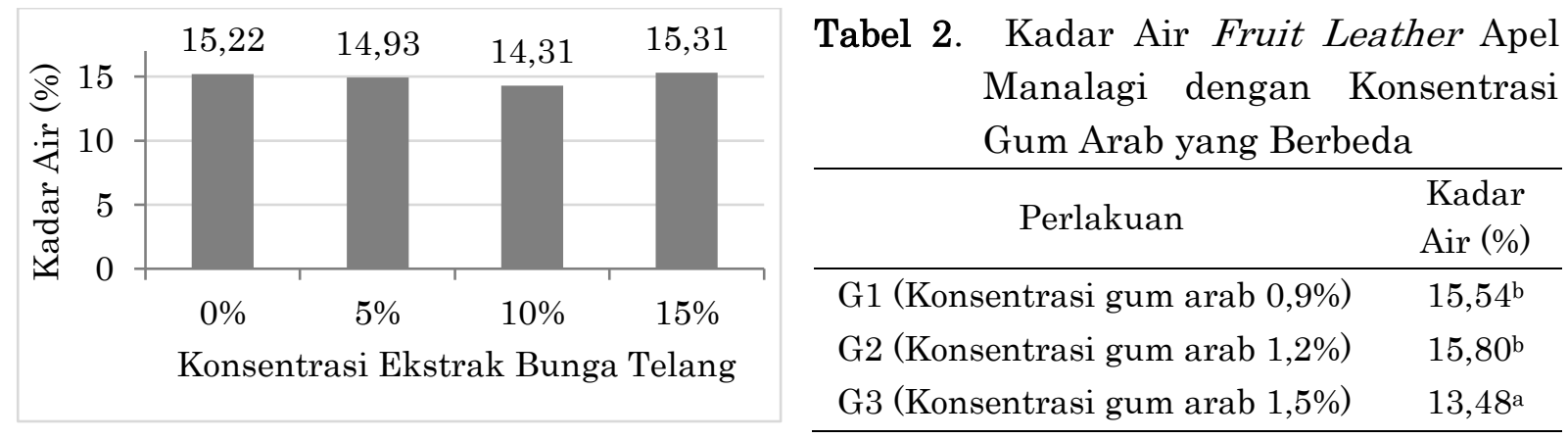

Gambar 1. Histogram Kadar Air Fruit Leather Apel Manalagi

Keterangan : Angka yang diikuti notasi huruf dengan Konsentrasi Ekstrak Bunga Telang yang Berbeda berbeda menunjukkan perbedaan nyata berdasarkan uji DMRT pada taraf $5 \%$

Berdasarkan Gambar 1 menunjukkan kadar air fruit leather berkisar antara 13,48\%-15,80\%. Hasil ini sesuai dengan Rizkianiputri dkk. (2016) bahwa kadar air fruit leather apel manalagi berkisar antara 13,84\%-18,57\%. Rendahnya kadar air dapat dikarenakan ekstrak bunga telang yang cair menyebabkan kadar air sebelum pengeringan lebih tinggi, sehingga semakin banyak air yang teruapkan selama pengeringan. Sesuai dengan Martini dkk. (2020) bahwa semakin banyak jumlah air yang diuapkan maka kadar air yang terukur menjadi rendah. Kadar air yang tinggi dapat disebabkan kandungan air tidak dapat diuapkan secara maksimal pada suhu dan waktu pengeringan yang sama. Hal ini sesuai dengan Banamtuan dkk. (2018) bahwa penambahan ekstrak rosella yang terlalu banyak menyebabkan kadar air produk meningkat.

Berdasarkan Tabel 2 menunjukkan semakin banyak gum arab yang ditambahkan maka kadar air semakin rendah. Hal ini dapat disebabkan gum arab mampu mengikat air namun daya ikat air gum arab tergolong rendah sehingga air lebih mudah diuapkan selama pengeringan. Hal ini sesuai dengan Praseptiangga dkk. (2016) bahwa kemampuan mengikat air (water holding capacity) gum arab tergolong rendah dibanding jenis hidrokoloid lain, kemampuan mengikat air dipengaruhi kandungan protein yang memiliki gugus fungsional untuk mengikat air. 


\section{Nilai pH Fruit Leather Apel Manalagi}

Berdasarkan hasil analisa ragam menunjukkan bahwa tidak terjadi interaksi antara perlakuan konsentrasi ekstrak bunga telang dan gum arab. Secara terpisah konsentrasi ekstrak bunga telang dan gum arab yang berbeda memberikan pengaruh sangat nyata $(\alpha=1 \%)$ terhadap nilai $\mathrm{pH}$ fruit leather apel manalagi.

Tabel 3. Nilai pH Fruit Leather Apel Manalagi dengan Konsentrasi Ekstrak Bunga Telang dan Gum Arab yang Berbeda

\begin{tabular}{lc}
\hline \multicolumn{1}{c}{ Perlakuan } & Nilai pH \\
\hline T0 (Konsentrasi ekstrak bunga telang 0\%) & $4,39^{\mathrm{d}}$ \\
T1 (Konsentrasi ekstrak bunga telang 5\%) & $4,22^{\mathrm{c}}$ \\
T2 (Konsentrasi ekstrak bunga telang 10\%) & $3,96^{\mathrm{b}}$ \\
T3 (Konsentrasi ekstrak bunga telang 15\%) & $3,87^{\mathrm{a}}$ \\
\hline G1 (Konsentrasi gum arab 0,9\%) & $4,05^{\mathrm{a}}$ \\
G2 (Konsentrasi gum arab 1,2\%) & $4,11^{\mathrm{b}}$ \\
G3 (Konsentrasi gum arab 1,5\%) & $4,17^{\mathrm{c}}$
\end{tabular}

Keterangan : Angka yang diikuti notasi huruf berbeda menunjukkan perbedaan nyata berdasarkan uji DMRT pada taraf $1 \%$

Berdasarkan Tabel 3 menunjukkan nilai $\mathrm{pH}$ fruit leather berkisar antara 3,87-4,39. Hal ini sesuai dengan hasil penelitian Risti dan Netti (2017) bahwa fruit leather sirsak-melon memiliki nilai $\mathrm{pH}$ berkisar antara 3,90-4,38. Semakin banyak ekstrak bunga telang yang ditambahkan maka nilai $\mathrm{pH}$ fruit leather semakin rendah. Penambahan asam sitrat pada proses ekstraksi bunga telang dan pembuatan fruit leather menyebabkan penurunan nilai $\mathrm{pH}$ bahan. Asam sitrat berperan sebagai penambah cita rata, pengawet dan membantu memperbaiki tekstur fruit leather dengan cara menurunkan $\mathrm{pH}$. Asam sitrat akan mengondisikan pektin agar pembentukan gel lebih cepat, sehingga gel yang dihasilkan lebih halus (Kamaluddin dan Handayani, 2018).

Nilai $\mathrm{pH}$ fruit leather (Tabel 3) meningkat dengan semakin banyak gum arab yang ditambahkan. Gum arab memiliki nilai $\mathrm{pH}$ yang lebih tinggi dibanding bahan baku, sehingga semakin banyak penambahan gum arab maka nilai $\mathrm{pH}$ semakin tinggi. Nilai pH gum arab sebesar 4,7 (Susianti dkk., 2020). Nilai pH fruit leather lebih tinggi daripada bubur buah apel manalagi karena adanya penambahan gula karena sifat gula yang cenderung menetralkan asam.

\section{Kuat Tarik Fruit Leather Apel Manalagi}

Berdasarkan hasil analisa ragam menunjukkan tidak terjadi interaksi antara konsentrasi ekstrak bunga telang dan gum arab. Secara terpisah 
konsentrasi ekstrak bunga telang berpengaruh nyata $(\alpha=5 \%)$, sedangkan konsentrasi gum arab berpengaruh sangat nyata $(\alpha=1 \%)$ terhadap nilai kuat tarik fruit leather apel manalagi.

Berdasarkan Tabel 4 menunjukkan bahwa konsentrasi ekstrak bunga telang 5\% menjadi nilai optimum konsentrasi penambahan terhadap karakteristik kuat tarik fruit leather. Peningkatan konsentrasi ekstrak bunga telang menurunkan nilai kuat tarik karena tingginya kandungan air bahan dapat mengganggu pembentukan gel. Sesuai dengan Fahrizal dan Fhadil (2014) bahwa keseimbangan air dan pektin yang terganggu dapat mempengaruhi pembentukan struktur gel sehingga gel yang dihasilkan tidak terlalu baik.

Tabel 4. Kuat Tarik Fruit Leather Apel Manalagi dengan Konsentrasi Ekstrak Bunga Telang dan Gum Arab yang Berbeda

\begin{tabular}{lc}
\hline Perlakuan & Kuat Tarik (N) \\
\hline T0 (Ekstrak bunga telang 0\%) & $14,89^{\mathrm{a}}$ \\
T1 (Ekstrak bunga telang 5\%) & $21,95^{\mathrm{b}}$ \\
T2 (Ekstrak bunga telang 10\%) & $14,45^{\mathrm{a}}$ \\
T3 (Ekstrak bunga telang 15\%) & $15,30^{\mathrm{a}}$ \\
\hline G1 (Gum arab 0,9\%) & $11,70^{\mathrm{a}}$ \\
G2 (Gum arab 1,2\%) & $15,07^{\mathrm{b}}$ \\
G3 (Gum arab 1,5\%) & $23,18^{\mathrm{c}}$ \\
\hline
\end{tabular}

Keterangan : Angka yang diikuti notasi huruf yang sama menunjukkan tidak berbeda nyata berdasarkan uji DMRT pada taraf $5 \%$

Nilai kuat tarik (Tabel 4) meningkat dengan semakin banyak konsentrasi gum arab yang ditambahkan. Sesuai dengan Praseptiangga dkk. (2016) bahwa semakin banyak gum arab yang ditambahkan maka tingkat ketahanan tarik fruit leather menjadi semakin tinggi. Hal ini dapat disebabkan gum arab yang memiliki kemampuan mengikat air dan membantu membentuk gel sehingga menghasilkan tekstur yang lebih kompak dan plastis. Nilai kuat tarik dipengaruhi oleh penurunan kadar air. Menurut Puspaningrum dkk. (2018), kadar air yang semakin rendah memberikan pengaruh terhadap peningkatan nilai kuat tarik fruit leather karena ikatan matriks bahan yang semakin kokoh dan erat.

\section{Intensitas Warna Fruit Leather Apel Manalagi}

Berdasarkan hasil analisa ragam menunjukkan bahwa tidak terjadi interaksi antara konsentrasi ekstrak bunga telang dan gum arab. Secara terpisah konsentrasi ekstrak bunga telang memberikan pengaruh sangat nyata $(\alpha=1 \%)$ sedangkan konsentrasi gum arab tidak berpengaruh nyata terhadap nilai intensitas warna.

Berdasarkan Tabel 5 menunjukkan semakin banyak penambahan ekstrak bunga telang maka tingkat kecerahan semakin menurun. Hal ini dikarenakan 
konsentrasi pigmen antosianin dari ekstrak bunga telang semakin meningkat sehingga warna semakin gelap. Menurut Saati dkk. (2011), berkurangnya nilai kecerahan menunjukkan pigmen memiliki potensi yang besar sebagai pewarna alami. Terjadi penurunan nilai a dan nilai b, dimana warna ungu memiliki warna dasar merah dan biru. Fruit leather dengan konsentrasi ekstrak bunga telang 15\% memiliki nilai $b^{-}$yang menunjukkan warna biru. Hal ini dapat disebabkan kandungan antosianin yang semakin pekat sehingga tingkat kebiruan meningkat. Menurut Sari dkk. (2005), tingkat kebiruan (b-) meningkat karena antosianin dalam bentuk kation flavilium yang berwarna merah mengalami degradasi menjadi bentuk basa kuinoidal yang berwarna biru.

Tabel 5. Intensitas Warna Fruit Leather Apel Manalagi dengan Konsentrasi Ekstrak Bunga Telang Berbeda

\begin{tabular}{cccc}
\hline Perlakuan & L & a+ & b \\
\hline T0 (Ekstrak bunga telang 0\%) & $64,4^{\mathrm{d}}$ & $10,5^{\mathrm{b}}$ & $+30,33^{\mathrm{c}}$ \\
T1 (Ekstrak bunga telang 5\%) & $49,2^{\mathrm{c}}$ & $6,75^{\mathrm{a}}$ & $+7,55^{\mathrm{b}}$ \\
T2 (Ekstrak bunga telang 10\%) & $43,7^{\mathrm{b}}$ & $7,15^{\mathrm{a}}$ & $+0,07^{\mathrm{a}}$ \\
T3 (Ekstrak bunga telang 15\%) & $41,1^{\mathrm{a}}$ & $6,92^{\mathrm{a}}$ & $-0,93^{\mathrm{a}}$ \\
\hline
\end{tabular}

Keterangan : Angka yang diikuti notasi huruf berbeda menunjukkan perbedaan nyata berdasarkan uji DMRT pada taraf $1 \%$

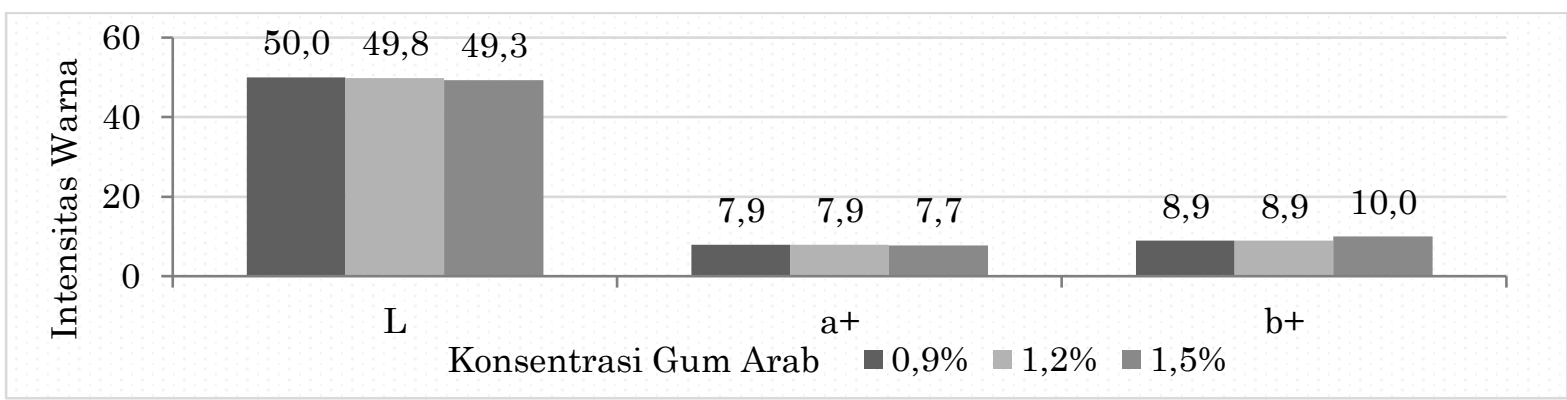

Gambar 2. Histogram Intensitas Warna Fruit Leather Apel Manalagi dengan Konsentrasi Gum Arab yang Berbeda

Berdasarkan Gambar 2 menunjukkan penambahan gum arab tidak berpengaruh nyata terhadap intensitas warna. Hal ini dapat dikarenakan gum arab ketika larut menjadi tidak berwarna. Menurut Ketaren dkk., (2017) semakin banyak penambahan gum arab menyebabkan bubur buah saat pemanasan menjadi lebih kental sehingga fruit leather yang dihasilkan berwarna lebih gelap. Fruit leather yang dihasilkan memiliki nilai a+ yang menunjukkan warna merah sedangkan nilai $b+$ menunjukkan warna kuning, dimana nilai tidak berbeda nyata antar perlakuan. Gum arab memiliki warna putih kekuningan sehingga konsentrasi yang semakin tinggi dapat membantu meningkatkan warna kekuningan. 


\section{Aktivitas Antioksidan Fruit Leather Apel Manalagi}

Berdasarkan hasil analisa ragam menunjukkan tidak terjadi interaksi antara konsentrasi ekstrak bunga telang dan gum arab. Secara terpisah konsentrasi ekstrak bunga telang berpengaruh sangat nyata $(a=1 \%)$ dan konsentrasi gum arab tidak berpengaruh nyata terhadap aktivitas antioksidan fruit leather.

Tabel 6. Aktivitas Antioksidan Fruit Leather Apel Manalagi dengan Konsentrasi Ekstrak Bunga Telang Berbeda

\begin{tabular}{cc}
\hline Perlakuan & $\begin{array}{c}\text { Aktivitas } \\
\text { Antioksidan } \\
(\%)\end{array}$ \\
\hline T0 (Ekstrak bunga telang 0\%) & $94,75^{\mathrm{d}}$ \\
T1 (Ekstrak bunga telang 5\%) & $93,40^{\mathrm{c}}$ \\
T2 (Ekstrak bunga telang 10\%) & $92,31^{\mathrm{b}}$ \\
T3 (Ekstrak bunga telang 15\%) & $90,42^{\mathrm{a}}$ \\
\hline
\end{tabular}

Keterangan : Angka yang diikuti notasi huruf berbeda menunjukkan perbedaan nyata berdasarkan uji DMRT pada taraf $1 \%$

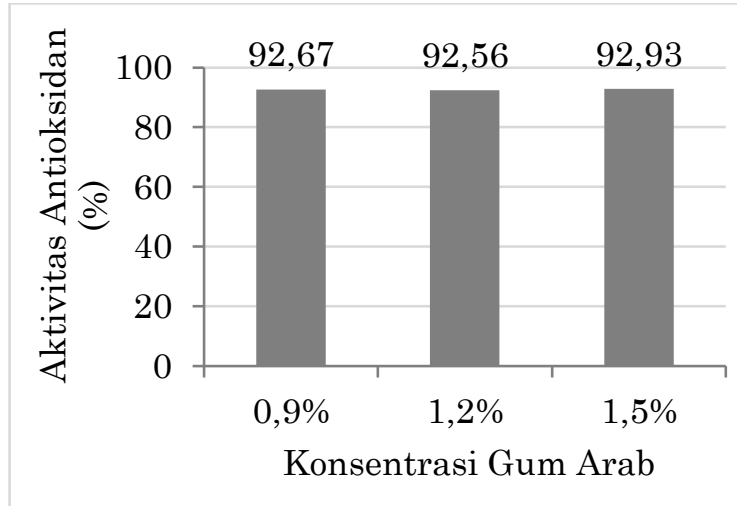

Gambar 3. Histrogram Aktivitas Antioksidan Fruit Leather Apel Manalagi dengan Konsentrasi Gum Arab yang Berbeda

Berdasarkan Tabel 6 menunjukkan semakin banyak ekstrak bunga telang yang ditambahkan maka aktivitas antioksidan mengalami penurunan. Penurunan aktivitas antioksidan dapat terjadi karena pigmen antosianin yang berperan sebagai antioksidan pada ekstrak bunga telang terperangkap dalam gel selama pembentukan tekstur oleh pektin dan gum arab. Semakin banyak ekstrak bunga telang yang ditambahkan, kadar air bubur apel manalagi semakin meningkat. Hal ini menyebabkan semakin banyak air yang dapat teruapkan selama pengeringan, sehingga senyawa antioksidan yang larut air dapat ikut menguap. Kenaikan $\mathrm{pH}$ dan kadar air fruit leather sebelum pengeringan karena adanya penambahan gum arab dan bahan lain yang mengurangi kestabilan antosianin sehingga mudah mengalami degradasi selama pengeringan. Menurut Fajarwati dkk. (2017), penurunan aktivitas antioksidan dapat terjadi karena degradasi antosianin yang berubah menjadi bentuk chalcone tidak berwarna yang cincinnya terbuka (bersifat labil). Tingginya aktivitas antioksidan fruit leather dapat berasal dari bubur apel manalagi yang lebih dominan. Apel manalagi memiliki senyawa fenolik utama yaitu kuersetin sebesar 406,57 mg/L (Cempaka dkk., 2014) dan vitamin C sebesar 12,08 mg/100 g (Putri dkk, 2017).

Berdasarkan Gambar 3 menunjukkan konsentrasi gum arab yang berbeda tidak berpengaruh terhadap aktivitas antioksidan. Penambahan gum arab dapat 
membantu mempertahankan kandungan pada bahan karena memiliki kemampuan untuk membentuk lapisan tipis pada permukaan produk selama pengeringan. Hal ini sesuai dengan Rini dkk. (2016) gum arab akan membentuk lapisan sehingga dapat melindungi asam askorbat dalam bahan yang sensitif terhadap oksidasi.

\section{Organoleptik (Kenampakan, Aroma, Rasa) Fruit Leather Apel Manalagi}

Berdasarkan hasil analisa ragam menunjukkan terdapat interaksi antara konsentrasi ekstrak bunga telang dan gum arab terhadap organoleptik fruit leather. Perlakuan konsentrasi ekstrak bunga telang dan gum arab berpengaruh nyata $(\alpha=5 \%)$ terhadap organoleptik fruit leather.

Tabel 7. Organoleptik (Kenampakan, Aroma, Rasa) Fruit Leather Apel Manalagi dengan Konsentrasi Ekstrak Bunga Telang dan Gum Arab Berbeda

\begin{tabular}{cccc}
\hline Kombinasi Perlakuan & Kenampakan & Aroma & Rasa \\
\hline T0G1 (Ekstrak bunga telang 0\% dan gum arab 0,9\%) & $3,76^{\text {cde }}$ & $3,44^{\mathrm{a}}$ & $3,92^{\mathrm{b}}$ \\
T0G2 (Ekstrak bunga telang 0\% dan gum arab 1,2\%) & $3,72^{\text {cd }}$ & $3,40^{\mathrm{a}}$ & $3,68^{\mathrm{b}}$ \\
T0G3 (Ekstrak bunga telang 0\% dan gum arab 1,5\%) & $3,84^{\text {cde }}$ & $3,40^{\mathrm{a}}$ & $3,80^{\mathrm{b}}$ \\
T1G1 (Ekstrak bunga telang 5\% dan gum arab 0,9\%) & $3,56^{\mathrm{bc}}$ & $3,44^{\mathrm{a}}$ & $3,80^{\mathrm{b}}$ \\
T1G2 (Ekstrak bunga telang 5\% dan gum arab 1,2\%) & $3,32^{\mathrm{ab}}$ & $3,56^{\mathrm{ab}}$ & $3,68^{\mathrm{b}}$ \\
T1G3 (Ekstrak bunga telang 5\% dan gum arab 1,5\%) & $3,08^{\mathrm{a}}$ & $3,32^{\mathrm{a}}$ & $3,08^{\mathrm{a}}$ \\
T2G1 (Ekstrak bunga telang 10\% dan gum arab 0,9\%) & $3,88^{\text {cde }}$ & $3,40^{\mathrm{a}}$ & $3,60^{\mathrm{b}}$ \\
T2G2 (Ekstrak bunga telang 10\% dan gum arab 1,2\%) & $4,08^{\text {de }}$ & $3,68^{\mathrm{ab}}$ & $3,96^{\mathrm{b}}$ \\
T2G3 (Ekstrak bunga telang 10\% dan gum arab 1,5\%) & $3,80^{\text {cde }}$ & $3,68^{\mathrm{ab}}$ & $3,72^{\mathrm{b}}$ \\
T3G1 (Ekstrak bunga telang 15\% dan gum arab 0,9\%) & $4,12^{\mathrm{e}}$ & $3,80^{\mathrm{b}}$ & $3,92^{\mathrm{b}}$ \\
T3G2 (Ekstrak bunga telang 15\% dan gum arab 1,2\%) & $3,92^{\text {cde }}$ & $3,36^{\mathrm{a}}$ & $3,72^{\mathrm{b}}$ \\
T3G3 (Ekstrak bunga telang 15\% dan gum arab 1,5\%) & $3,92^{\text {cde }}$ & $3,64^{\text {ab }}$ & $3,68^{\mathrm{b}}$ \\
\hline
\end{tabular}

Keterangan : Kenampakan ( $1=$ sangat tidak menarik, $2=$ tidak menarik, $3=$ cukup menarik, $4=$ menarik, $5=$ sangat menarik). Aroma ( $1=$ sangat tidak khas apel, $2=$ tidak khas apel, $3=$ cukup khas apel, $4=$ khas apel, $5=$ sangat khas apel). Rasa ( $1=$ sangat tidak enak, $2=$ tidak enak, $3=$ cukup enak, $4=$ enak, $5=$ sangat enak). Angka yang diikuti notasi huruf berbeda menunjukkan perbedaan nyata berdasarkan uji DMRT pada taraf 5\%

Berdasarkan Tabel 7 menunjukkan skor organoleptik kenampakan, aroma dan rasa fruit leather apel manalagi. Kenampakan fruit leather yang dihasilkan berada pada tingkat cukup menarik hingga menarik. Semakin banyak ekstrak bunga telang yang ditambahkan maka kenampakan fruit leather semakin menarik, karena warna ungu pada fruit leather semakin pekat. Ekstrak bunga telang mengandung antosianin yang memiliki potensi sebagai pewarna alami makanan dan menjadi alternatif untuk mengurangi penggunaan pewarna sintetik (Saati dkk., 2018). Penambahan konsentrasi gum arab menyebabkan skor kenampakan menurun, hal ini dapat disebabkan warna produk yang semakin gelap. Sesuai dengan Ketaren dkk. (2017) bahwa konsentrasi gum arab yang 
semakin tinggi menyebabkan larutan fruit leather semakin kental selama pemasakan sehingga warna produk yang dihasilkan semakin gelap.

Fruit leather yang dihasilkan memiliki aroma cukup khas apel hingga khas apel. Penambahan ekstrak bunga telang tidak mengurangi aroma khas apel pada fruit leather yang dihasilkan. Menurut Martini dkk. (2020) bahwa paparan panas dalam waktu yang lama dapat menyebabkan penguapan senyawa volatil pada bahan. Konsentrasi ekstrak bunga telang lebih sedikit dibanding bubur apel manalagi, sehingga aroma khas apel lebih dominan. Buah apel manalagi memiliki aroma yang lebih harum dibanding jenis apel lain meskipun belum matang (Hapsari dan Estiasih, 2015). Menurut Susianti dkk. (2020), gum arab tidak memiliki aroma yang dapat mengganggu, namun dapat melapisi senyawa aroma untuk membantu mempertahankan aroma produk yang dikeringkan.

Fruit leather yang dihasilkan memiliki rasa yang cukup enak hingga enak. Penambahan ekstrak bunga telang yang semakin banyak memberikan rasa cenderung asam yang disukai. Pembuatan fruit leather juga menambahkan asam sitrat sebagai asidulan yang berperan sebagai penegas rasa atau menutupi after taste yang tidak diinginkan (Asasia dan Yuwono, 2018). Penambahan gum arab bertujuan untuk membantu memperbaiki tekstur fruit leather. Gum arab termasuk hidrokoloid yang tidak memiliki rasa, dimana penambahan dengan konsentrasi tinggi menyebabkan fruit leather semakin hambar karena rasa asam dan manis semakin tertutupi (Khairunnisa dkk., 2015).

\section{Perlakuan Terbaik}

Berdasarkan Tabel 8 dapat diketahui bahwa perlakuan terbaik diperoleh pada perlakuan T3G3 (ekstrak bunga telang 15\% dan gum arab 1,5\%). Fruit leather perlakuan T3G3 memiliki kadar air 13,23\%, nilai $\mathrm{pH} 3,91$, nilai kuat tarik $26,35 \mathrm{~N}$, aktivitas antioksidan 90,62\%, tingkat kecerahan (L) 41,4, tingkat kemerahan $(\mathrm{a}+)+6,7$, tingkat kebiruan (b-) - 0,6 . Hasil organoleptik perlakuan terbaik meliputi organoleptik kenampakan 3,92 (menarik), organoleptik aroma 3,64 (khas apel), dan organoleptik rasa 3,68 (enak). Hal ini menunjukkan bahwa panelis menyukai atribut organoleptik pada perlakuan T3G3. Menurut Nurlaely (2002), fruit leather memiliki kadar air 10-20\%, tekstur yang plastis, kenampakan mengkilat seperti kulit, memiliki aroma, warna dan cita rasa yang khas sesuai bahan yang digunakan sebagai bahan baku. Fruit leather perlakuan T3G3 telah memenuhi standar manisan kering menurut SNI No. 1718:1996 yaitu kadar air maksimal 25\%, keadaan (kenampakan, bau, dan rasa) normal dan tidak berjamur. 
Tabel 8. Perlakuan Terbaik Metode De Garmo

\begin{tabular}{ccc}
\hline Kombinasi Perlakuan & Total & Ranking \\
\hline T0G1 (Ekstrak bunga telang 0\% dan gum arab 0,9\%) & 0,437 & 11 \\
T0G2 (Ekstrak bunga telang 0\% dan gum arab 1,2\%) & 0,398 & 12 \\
T0G3 (Ekstrak bunga telang 0\% dan gum arab 1,5\%) & 0,529 & 6 \\
T1G1 (Ekstrak bunga telang 5\% dan gum arab 0,9\%) & 0,476 & 7 \\
T1G2 (Ekstrak bunga telang 5\% dan gum arab 1,2\%) & 0,466 & 8 \\
T1G3 (Ekstrak bunga telang 5\% dan gum arab 1,5\%) & 0,458 & 10 \\
T2G1 (Ekstrak bunga telang 10\% dan gum arab 0,9\%) & 0,530 & 5 \\
T2G2 (Ekstrak bunga telang 10\% dan gum arab 1,2\%) & 0,686 & 2 \\
T2G3 (Ekstrak bunga telang 10\% dan gum arab 1,5\%) & 0,661 & 3 \\
T3G1 (Ekstrak bunga telang 15\% dan gum arab 0,9\%) & 0,602 & 4 \\
T3G2 (Ekstrak bunga telang 15\% dan gum arab 1,2\%) & 0,460 & 9 \\
T3G3 (Ekstrak bunga telang 15\% dan gum arab 1,5\%) & 0,688 & 1 \\
\hline
\end{tabular}

\section{Total Antosianin Fruit Leather Apel Manalagi}

Analisa total antosianin dilakukan pada 2 perlakuan terbaik dan 1 perlakuan tanpa penambahan ekstrak bunga telang sebagai kontrol. Menurut Thuy dkk. (2021) pada bunga telang ditemukan antosianidin yang dominan dalam bentuk delfinidin dan sianidin.

Tabel 9. Total Antosianin Fruit Leather Apel Manalagi

\begin{tabular}{cc}
\hline Kombinasi Perlakuan & Total Antosianin (mg/L) \\
\hline T0G2 (Ekstrak bunga telang 0\% dan gum arab 1,2\%) & 0,00 \\
T3G3 (Ekstrak bunga telang 15\% dan gum arab 1,5\%) & 1,06 \\
T2G2 (Ekstrak bunga telang 10\% dan gum arab 1,2\%) & 1,52 \\
\hline
\end{tabular}

Berdasarkan Tabel 9 menunjukkan bahwa total antosianin tertinggi pada perlakuan ekstrak bunga telang $10 \%$. Hal ini dapat disebabkan karena pada perlakuan T3G3 penambahan gum arab lebih banyak dibanding perlakuan T2G2 sehingga $\mathrm{pH}$ fruit leather lebih tinggi. Peningkatan $\mathrm{pH}$ menyebabkan penurunan kestabilan dan perubahan struktur antosianin kearah yang tidak berwarna. Menurut Fajarwati dkk. (2017), penurunan total antosianin dapat terjadi karena degradasi antosianin yang berubah menjadi bentuk chalcone tidak berwarna yang cincinnya terbuka (bersifat labil). Antosianin yang kurang stabil mudah mengalami kerusakan selama proses pengolahan yang menggunakan panas, sehingga total antosianin perlakuan T3G3 lebih rendah dibandingkan dengan perlakuan T2G2. Antosianin dapat berperan sebagai antioksidan sehingga penurunan total antosianin sejalan dengan hasil analisa aktivitas antioksidan. 


\section{KESIMPULAN}

Berdasarkan data hasil penelitian diketahui bahwa konsentrasi ekstrak bunga telang dan konsentrasi gum arab memiliki interaksi terhadap skor organoleptik fruit leather apel manalagi. Perbedaan konsentrasi ekstrak bunga telang berpengaruh nyata terhadap nilai $\mathrm{pH}$, kuat tarik, intensitas warna, aktivitas antioksidan dan skor organoleptic, sedangkan konsentrasi gum arab berpengaruh nyata terhadap kadar air, nilai $\mathrm{pH}$, kuat tarik, dan skor organoleptik fruit leather apel manalagi. Fruit leather apel manalagi perlakuan terbaik adalah T3G3 (Konsentrasi ekstrak bunga telang 15\% dan gum arab 1,5\%) dengan nilai kadar air sebesar 13,23\%, nilai $\mathrm{pH} 3,91$, kuat tarik 26,35 N, aktivitas antioksidan 90,62\%, tingkat kecerahan (L) 41,4, tingkat kemerahan $(\mathrm{a}+)+6,7$, nilai kebiruan (b-) -0,6, skor organoleptik kenampakan 3,92 (menarik), skor aroma 3,64 (khas apel), skor rasa 3,68 (enak), dan total antosianin 1,06 mg/L.

\section{DAFTAR PUSTAKA}

Andriani, D., L. Murtisiwi. 2020. Uji Aktivitas Antioksidan Ekstrak Etanol 70\% Bunga Telang (Clitoria ternatea L) dari Daerah Sleman dengan Metode DPPH. Jurnal Farmasi Indonesia, 17(1), pp. 70-76. DOI : https://doi.org/10.23917/pharmacon.v17i1.9321

Anwar, E.N., Wahyuni, R. 2020. Pengaruh Proporsi Penambahan Daun Katok (Sauropus androgynus L. Merr.) terhadap Sifat Fisikokimia Selai Lembaran Apel. Jurnal Teknologi Pangan, 11(1), pp. 79-87. DOI : https://doi.org/10.35891/tp.v11i1.1926

AOAC. 2005. Offiial Methods of Analysis Association of Official Analytical. Washington : Chemist INC.

Asasia, P.A.A., Yuwono, S.S. 2018. Pengaruh Konsentrasi Tepung Maizena dan Konsentrasi Asam Sitrat terhadap Sifat Fisik, Kimia dan Organoleptik Selai Mawar. Jurnal Pangan dan Agroindustri, 6(1), pp. 64-74. DOI : http://dx.doi.org/10.21776/ub.jpa.2018.006.01.8

ASTM. 1993. Annual Book of ASTM Standards. Philadelpia : American Society for Testing and Material.

Astuti T., Widowati E. \& Atmaka W. 2015. Kajian Karakteristik Sensoris, Fisik, dan Kimia Fruit Leather Pisang Tanduk (Musa corniculata Lour.) dengan Penambahan Berbagai Konsentrasi Gum Arab. Jurnal Teknologi Hasil Pertanian. 8(1), pp. 6-14. DOI : https://doi.org/10.20961/jthp.v0i0.12786

Badan Standardisasi Nasional. 2004. Air dan Air Limbah SNI 06-6989. Jakarta : BSN.

Banamtuan, A.N., G.M. Sipahelut, G.E.M. Malelak. 2018. Pengaruh Penggunaan Ekstrak Rosela (Hibiscus sabdariffa L.) terhadap Kualitas Kimia Se’i 
Sapi. Jurnal Nukleus Peternakan, 5(1), pp. 64-70. DOI : https://doi.org/10.35508/nukleus.v5i1.838

Cempaka, A.R., Santoso, A., Tanuwijaya, L.K. 2014. Pengaruh Metode Pengolahan (Juicing dan Blending) terhadap Kandungan Kuersetin Berbagai Varietas Apel Lokal dan Impor (Malus domestica). Indonesian Journal of Human Nutrition, 1(1), pp. 14-22.

Cristiana, M. A., L. E. Radianti, Purwadi. 2015. Pengaruh Gum Arab pada Minuman Madu Sari Apel Ditinjau dari Mutu Organoleptik, Warna, pH, Viskositas dan Kekeruhan. Jurnal Ilmu dan Teknologi Hasil Ternak, 10(2), pp. 46-53. DOI : https://doi.org/10.21776/ub.jitek.2015.010.02.5

De Garmo, E.P., W.E. Sullevan, Canana. 1984. Engineering Economy, Seventh Edition. New York : Pretince Hall Inc.

Dewi, A. P., Triana S., Juni S. 2019. Pengaruh Penambahan Bunga Telang (Clitoria ternatea) terhadap Sineresis dan Tingkat Kesukaan Yogurt Susu Kambing. Journal of Animal Science and Technology. 1 (2), pp. 145-151

Dimyati, K.K.H., M.Z. Muzakkar, Hermanto. 2020. Pengaruh Konsentrasi Penambahan Gum Arab terhadap Karakteristik Organoleptik dan Kimia Fruit Leather Pisang Raja (Musa paradisiaca var. Raja). Jurnal Sains dan Teknologi Pangan, 5(1), pp. 2753-2765. DOI : http://dx.doi.org/10.33772/jstp.v5i1.11547

Fahrizal, Fadhil, R. 2014. Kajian Fisiko Kimia dan Daya Terima Organoleptik Selai Nenas yang Menggunakan Pektin dari Limbah Kulit Kakao. Jurnal Teknologi dan Industri Pertanan Indonesia, 6(3), pp. 65-68. DOI : https://doi.org/10.17969/jtipi.v6i3.2314

Fajarwati, N.H., Parnanto, N.H.R., Manuhara, G.J. 2017. Pengaruh Konsentrasi Asam Sitrat dan Suhu Pengeringan terhadap Karakteristik Fisik, Kimia dan Sensoris Manisan Kering Labu Siam (Sechium edule $S_{W}$.) dengan Pemanfaatan Pewarna Alami dari Ekstrak Rosela Ungu (Hibiscus sabdariffa L.). Jurnal Teknologi Hasil Pertanian, 10(1), pp. 50-66. DOI : https://doi.org/10.20961/jthp.v10i1.17494

Hapsari, M.D.Y., T. Estiasih. 2015. Variasi Proses dan Grade Apel (Malus sylvestris Mill) pada Pengolahan Minuman Sari Buah Apel : Kajian Pustaka. Jurnal Pangan dan Agroindustri, 3(3), pp. 939-949.

Kamaluddin, M.J.N., M.N. Handayani. 2018. Pengaruh Perbedaan Jenis Hidrokoloif terhadap Karakteristik Fruit Leather Pepaya. Edufortech, 3(1), pp. 25-32. DOI : https://doi.org/10.17509/edufortech.v3i1.13542

Ketaren, E.P., Ginting, S., Julianti, E. 2017. Pengaruh Perbandingan Gum Arab dengan Pektin sebagai Penstabil terhadap Mutu Selai Wortel Nanas. Jurnal Rekayasa Pangan dan Pertanian, 5(1), pp. 136-139. 
Khairunisa, A., Atmaka. W., dan Widowati, E. 2015. Pengaruh Penambahan Hidrokoloid (CMC dan Agar-Agar Tepung) Terhadap Sifat Fisik, Kimia, dan Sensoris Fruit Leather Semangka (Citrull lanatus (thumb) Mastum). Et Nakai). Jurnal Teknosains Pangan, 4(1), pp. 1-9.

Martini, N. K. A., Ekawati, I. G. A., Ina, P. T. 2020. Pengaruh Suhu dan Lama Pengeringan terhadap Karakteristik Teh Bunga Telang (Clitoria ternatea L.). Jurnal Itepa, 9(3), pp. 327-340. DOI : https://doi.org/10.24843/itepa.2020.v09.i03.p09

Nurlaely E, 2002. Pemanfaatan Buah Jambu Mete untuk Pembuatan Leather, Kajian dari Proporsi Buah Pencampur. Skripsi. Unversitas Brawaijaya.

Praseptiangga, D., T.P. Aviany, N.H.R. Parmanto. 2016. Pengaruh Penambahan Gum Arab terhadap Karakteristik Fisikokimia dan Sensoris Fruit Leather Nangka (Artocarpus heterophyllus). Jurnal Teknologi Hasil Pertanian, 9(1), pp. 71-83. DOI : https://doi.org/10.20961/jthp.v9i2.12858

Puspaningrum, L., S. S. Yuwono, E. Martati. 2018. Karakteristik Fisikokimia dan Sensoris Fruit Leather Apel Manalagi (Malus sylvestris Mill.) dengan Subtitusi Pisang Candi (Musa paradisiaca). Jurnal Teknologi Pertanian, 1(3), pp. 173-182. DOI : http://dx.doi.org/10.21776/ub.jtp.2018.019.03.4

Putri, G.N., N. H. R. Parnanto, A. Nursiwi. 2016. Pengaruh Penambahan Gum Arab terhadap Karakteristik Fisik, Kimia dan Organoleptik Fruit and Vegetable Leather dari Albedo Semangka (Citrullus vulgaris Schard.) dan Wortel (Daucus carota). Jurnal Teknologi Pangan, 5(3), pp. 20-30.

Putri, G.N., W.H. Susanto, N. Wijayanti. 2017. Pengaruh Varietas Apel (Malus sylvestris Mill) dan Konsentrasi Maizena terhadap Karakteristik Lempok Apel. Jurnal Pangan dan Agroindustri, 5(2), pp. 12-22.

Rahmi, A, Susi, L. Agustina. 2013. Analisa Tingkat Kesukaan Konsumen, Penetapan Umur Simpan dan Analisis Kelayakan Usaha Dodol Pisang. Ziraa'ah, 37(2), pp. 26-32. DOI : http://dx.doi.org/10.31602/zmip.v37i2.42

Ramadhani, A.D. 2016. Karakteristik Fruit Leather Campuran Sirsak (Annona muricata L.) dan Wortel (Dsucus caota L.). Skripsi. Universitas Jember.

Rini, P.S., Nianggolan, R.J., Ridwansyah. 2016. Pengaruh Perbandingan Bubur Buah Sirsak (Annona muricata L.) dengan Bubur Bit (Beta vulgaris) dan Konsentrasi Gum Arab terhadap Mutu Fruit Leather. Jurnal Rekayasa Pangan dan Pertanian, 4(4), pp. 509-516.

Risti, A. P. dan Netti H. 2017. Pembuatan Fruit Leather dari Campuran Buah Sirsak (Annoma muricata L.) dan Buah Melon (Cucumis melo L.). JOM Fakultas Pertanian, 4 (2), pp.1-15

Rizkianiputri, D., W. Atmaka, A.M. Sari. 2016. Pendugaan Umur Simpan Fruit Leather Apel Manalagi (Malus sylvestris) Menggunakan Metode ASLT 
(Accelerated Shelf Life Test) dengan Model Arrhenius. Jurnal Teknologi Hasil Pertanian, 9 (2), pp. 40-50.

Saati, E.A., Mulandari, R.D. , Wachid, M., Winarsih, S. 2018. The Utilization of Telang Flower as Healthy-Natural Food Coloring on Dawet Drink. Proceedings of the $4^{\text {th }}$ International Symposium on Applied Chemistry. AIP Conference Proceedings. DOI : https://doi.org/10.1063/1.5064356

Saati, E.A., Theovilla, R.R.D., Simon, B.W., Aulanni'am. 2011. Optimalisasi Fungsi Pigmen Bunga Mawat Sortiran sebagai Zat Pewarna Alami dan Bioaktif pada Beberapa Produk Industri. Jurnal Teknik Industri, 12(2), pp. 133-140. DOI : $\underline{\text { https://doi.org/10.22219/JTIUMM.Vol12.No2.133-140 }}$

Sari, P., F. Agustina, M. Komar, Unus, M. Fauzi, T. Lindriati. 2005. Ekstraksi dan Stabilitas Antosianin dari Kulit Buah Duwet (Syzygium cumini). Jurnal Teknologi dan Industri Pangan, 16(2), pp. 142-150.

Sinaga, D.S.M., I. Suhaidi, Ridwansyah. 2017. Pengaruh Perbandingan Nanas dengan Bit dan Konsentrasi Gum Arab terhadap Mutu Fruit Leather Nanas. Jurnal Rekayasan Pangan dan Pertanian, 5(2), pp. 267-274.

Souripet, A. 2015. Komosisi, Sifat Fisik dan Tingkat Kesukaan Nasi Ungu. Jurnal Teknologi Pertanian, 4(1), pp. 25-32.

Standarisasi Nasional Indonesia No. 1718. 1996. Syarat Mutu Manisan Kering. Jakarta : Badan Standarisasi Nasional.

Susanto, W.H., B.R. Setyohadi. 2011. Pengaruh Varietas Apel (Malus sylvestris) dan Lama Fermentasi oleh Khamir Saccharomyces cerevisiae sebagai Perlakuan Pra-Pengolahan terhadap Karakteristik Sirup. Jurnal Teknologi Pertanian, 12(3), pp. 135-142.

Susianti, Amalia, U., Rianingsih, L. 2020. Penambahan Gum Arab dengan Konsentrasi yang Berbeda terhadap Kandungan Senyawa Volatil Bubuk Rusip Ikan Teri (Stolephorus sp.). Jurnal Ilmu dan Teknologi Perikanan, 2(1), pp. 10-19.

Thuy, N.M., Minh, V.Q., Ben, T.C., Nguyen, M.T.T., Ha, H.T.N., 2021. Identification of Anthocyanin Compounds in Butterfly Pea Flowers (Clitoria ternatea L.) by Ultra Performance Liquid Chromatography/Ultraviolet Coupled to Mass Spectrometry. Molecules, 26(15), pp. 1-13. DOI : https://doi.org/10.3390/molecules26154539

Yue, X. dan Xu, Z. 2008. Changes of Anthocyanins, Anthocyanidins, Antioxidant Activity in Bilberry Extract during Dry Heating. Journal of Food Science, 73, pp. 494-499. DOI : https://doi.org/10.1111/j.1750-3841.2008.00845.x

Zaddana, C., Almasyhuri, Shalatin, R.A. 2020. Selai Lembaran Kombinasi Apel (Malus sylvestris (L.) Mill.) dan Teh Hijau (Camellia sinensis L.) sebagai 
Food Technology and Halal Science Journal 05 (01) (2022) 15-31

Pangan Fungsional. Jurnal AcTion: Aceh Nutrition Journal, 5(1), pp. 87-97. DOI : $10.30867 /$ action.v5i1.267

Zussiva, A., B.K Laurent, C.S. Budiyati. 2012. Ekstraksi dan Analisis Zat Warna Biru (Anthosianin) dari Bunga Telang (Clitoria ternatea) sebagai Pewarna Alami. Jurnal Teknologi Kimia dan Industri, 1(1), pp. 356-365 